\title{
The Effect Of Chitin Size And Soaking Time On Decreasing Cholesterol Levels On Quail Eggs
}

\author{
Aisyah Vynkarini Daniar, Nuniek Herdyastuti* \\ Department of Chemistry, Faculty Mathematics and Natural Science \\ Universitas Negeri Surabaya \\ Surabaya, Indonesia \\ nuniekherdyastuti@unesa.ac.id
}

\begin{abstract}
Hypercholesterolemia is a symptom that shows an increase in cholesterol levels in the blood and can cause atherosclerosis which is a major factor for cardiovascular diseases such as coronary heart disease. Quail eggs are one of the foods that contain high cholesterol. Cholesterol content in quail eggs can be reduced by adsorption through soaking with chitin solution. This study aims to determine the effect of chitin size and soaking time on cholesterol in quail eggs. Analysis of cholesterol levels in quail eggs using the Rudel-Moris colorimetric method and the Zak method. The results showed that variations in chitin size and soaking time affected cholesterol in quail eggs. The highest percentage of cholesterol reduction was seen in the size of 300 mesh chitin with a percentage reduction of $75.6 \%$ and the best soaking time was 30 minutes with a percentage reduction of $71.5 \%$
\end{abstract}

Keywords-Quail egg, Cholesterol levels, Chitin

\section{INTRODUCTION}

Indonesian people like various types of food, but do not take into account the nutritional value and food ingredients. One of the unhealthy ingredients is high cholesterol content [1]. Quail eggs are one of the foods that contain high cholesterol. Quail yolk cholesterol level of $2138.17 \mathrm{mg} / 100$ $\mathrm{g}$, while chicken egg yolk cholesterol was only $1,274.4 \mathrm{mg} /$ $100 \mathrm{~g}$ [2].

Consumption of cholesterol foods in full. Hypercholesterolemia is a physical condition that shows high levels of cholesterol in the blood [3]. Hypercholesterolemia causes atherosclerosis and a major factor for cardiovascular diseases such as coronary heart disease [4]. Based on research that has been done, shrimp shell flour (carapace) in the ration can reduce levels of LDL (Low Density Lipoprotein) and increase HDL (High Density Lipoprotein) of meat [5].

Chitin is a polysaccharide, a linear polymer composed of its monomer $\beta-1,4-\mathrm{N}$-acetylglucosamine. Chitin abundance in nature is placed second largest after cellulose [6]. Chitin is able to reduce cholesterol adsorption more effectively than cellulose and has high hypocholesterolemic potential [5]. Addition of chitin from mangrove crab shells (Scylla spp) can also reduce brain fat levels up to $82.04 \%$ [7].

Quail eggshells consist of three layers, namely the solid cuticle layer and the mammillary layer and the palisade layer with many micron-containing pores [8]. Based on the characteristics of quail eggshells, cholesterol can be used with adsorption levels by chitin. In other studies, chitin is used as a mixture of animal feed and cholesterol levels in meat and eggs can be calculated [5] [9].

\section{RESEARCH MATERIALS AND PROCEDURES}

Material which use in this research are quail eggs (Wonokromo Market Surabaya), chitin from shrimp shells (Xi'an Rongsheng Biotechnology Co., Ltd.), absolute ethanol (Fulltime), $\mathrm{FeCl}_{3} \cdot 6 \mathrm{H}_{2} \mathrm{O}$ (Merck), glacial acetic acid (Fulltime), $\mathrm{H}_{2} \mathrm{SO}_{4}$ solution (Merck), chloroform (Merck), and aquademin. The tools used in this research are hotplate, analytical balance, centrifuge (Hettich EBA-20), magnetic stirrer (D-LAB MS7-H550 PRO), UV-Vis spectrophotometer (Shimadzu UV-1800), and commonly used glassware.

\section{A. Variations of Chitin Size on Cholesterol in Quail Eggs}

Chitin sifted in sizes 100, 200, and 300 mesh. Then, chitin with each size was weighed as much as 0.5 gram and dissolved using $100 \mathrm{~mL}$ of $1 \%$ acetic acid. Quail eggs are then put into chitin solution and incubated for 30 minutes.

\section{B. Variation of Incubation Time on Cholesterol in Quail Eggs}

300 mesh chitin weighed as much as 0.5 grams and dissolved using $100 \mathrm{~mL}$ of $1 \%$ acetic acid. Quail eggs are then put into chitin solution and incubated for 15 minutes, 30 minutes, 45 minutes, 60 minutes, and 120 minutes.

\section{Determination of Cholesterol Levels in Quail Eggs}

The analysis of cholesterol levels in this study used the colorimetric method of Rudel-Morris and the Zak Method using a UV-Vis spectrophotometer [7].

Soaked eggs are then removed from the chitin solution and taken as much as 2.5 grams of egg yolk. Then dissolve using $10 \mathrm{ml}$ of chloroform into a beaker, stirring on a hotplate for 1 hour until completely dissolved. Then centrifuged at a speed of $3000 \mathrm{rpm}$ for 20 minutes. Supernatant is separated by pellets and produced quail egg cholesterol extract.

Supernatant took as much as $0.5 \mathrm{ml}$ and then the volume was sufficient $5 \mathrm{ml}$ with absolute ethanol. Added $2 \mathrm{ml}$ of the $\mathrm{FeCl}_{3}$ reagent is then homogenized, allowed to stand for 10 minutes and covered with the outer layer of the tube. $1 \mathrm{ml}$ of $\mathrm{H}_{2} \mathrm{SO}_{4}$ (pa) was added and the mixture of solution was homogenized, then allowed to stand for 20 minutes. Cholesterol levels were determined by UV-Vis 
spectrophotometer at a wavelength of $426 \mathrm{~nm}$ and by using linear regression equations of standard solutions. The standard solution used is the concentration of $20,40,60,80$, and $100 \mathrm{ppm}$.

\section{RESULT AND DISCUSSION}

\section{A. Determination of Cholesterol Levels in Quail Eggs}

The determination of cholesterol in quail eggs in this study uses the colorimetric method of Rudel-Morris and the Zak method [7]. The principle of determining cholesterol by this method is based on the binding ability of cholesterol analyzed in a cholesterol-ethanol solution after the addition of a test sample. Cholesterol level analysis is done by reacting to the cholesterol that has been dissolved using ethanol with $\mathrm{FeCl}_{3}$ reagent and concentrated sulfuric acid.

Cholesterol levels were analyzed for absorbance using a $\mathrm{UV}-\mathrm{V}$ is spectrophotometer at a wavelength of $426 \mathrm{~nm}$. The absorbance value is the amount of light absorbed by the substance in the solution which is proportional to its concentration. The optimum wavelength obtained is 426 $\mathrm{nm}$. Making a standard curve first has to do to find out cholesterol levels in quail eggs. Cholesterol solutions used as a standard have concentrations of $20,40,60,80$, and 100 ppm. Cholesterol standard curves produce a linear regression equation that is $\mathrm{y}=0.0016 \mathrm{x}+0.0212$ with $\mathrm{R}^{2}=0.997$.

In this study, control was used, namely the level of cholesterol extract from quail eggs without treatment or without soaking with chitin solution. Control cholesterol levels are used to determine the percentage of cholesterol reduction in quail eggs after immersion with chitin solution. The control cholesterol level is $557.2 \mathrm{ppm}$.

Quail eggs used in this study were obtained from Wonokromo Market, Surabaya (Figure 1). Eggs that have been soaked with chitin solution are taken the yolk to extract cholesterol. Cholesterol is extracted using chloroform using a filter. The choice of chloroform for cholesterol extraction is based on polarity. Chloroform which is nonpolar is suitable for extracting cholesterol which tends to be nonpolar. Following the principle of like dissolve like, ie nonpolar compounds will dissolve in nonpolar solvents [10].

After being homogenized using a stirrer, cholesterol is then separated from the residue using a centrifuge. Centrifugation is a mechanical process that utilizes centrifugal force applications to separate components from a mixture according to the density and / or particle size [11]. At this stage centrifugation serves to precipitate cholesterol that has been bound to chitin, leaving a filtrate containing only cholesterol that is not bound to chitin. The results of cholesterol extraction are shown in Figure 1.

The results of cholesterol extraction are then added to ethanol. Ethanol functions to analyze cholesterol levels based on the ability of cholesterol binding in cholesterolethanol solution after adding test samples. Then a staining reaction is given between $\mathrm{FeCl}_{3}$ in glacial acetic acid and concentrated sulfuric acid as a catalyst, so that yellow compounds are formed and the amount of residual cholesterol in the sample is determined by measuring the absorption.

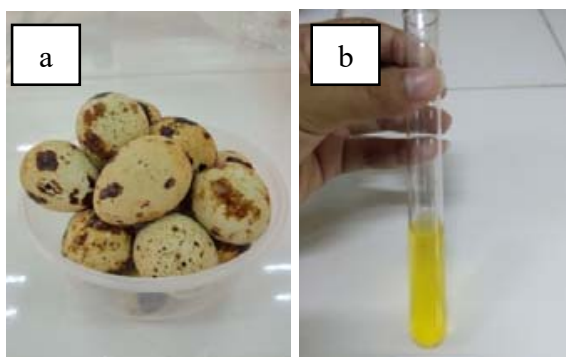

Fig. 1. Quail eggs which cholesterol will extract (a) Quail egg cholesterol extraction results (b)

\section{B. Variation of Chitin Size on Cholesterol in Quail Eggs}

In this study, the effect of chitin on cholesterol levels in quail eggs can be determined by soaking quail eggs using chitin solution. The effect of chitin size on cholesterol in quail eggs was studied using size variations of 100, 200, and 300 mesh. Chitin used in this study is shown in Figure 2.

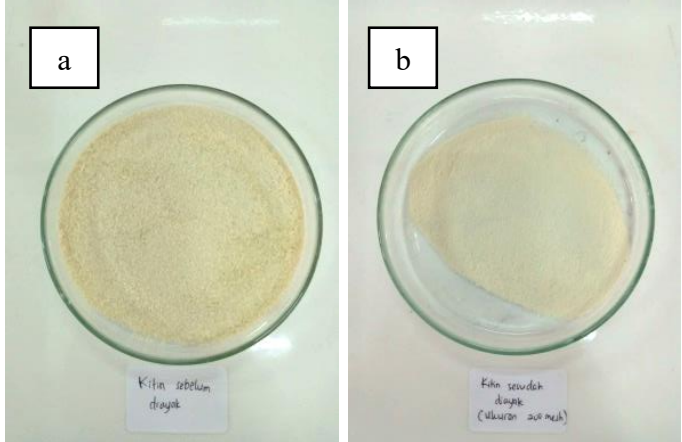

Fig. 2. (a) Chitin before sifting (b) 200 mesh chitin size

Chitin weight used is 0.5 grams and incubated for 30 minutes. Samples that have been analyzed and known concentration can be calculated as a percentage reduction in cholesterol. The results of the influence of chitin size variations on quail cholesterol levels are shown in Figure 3.

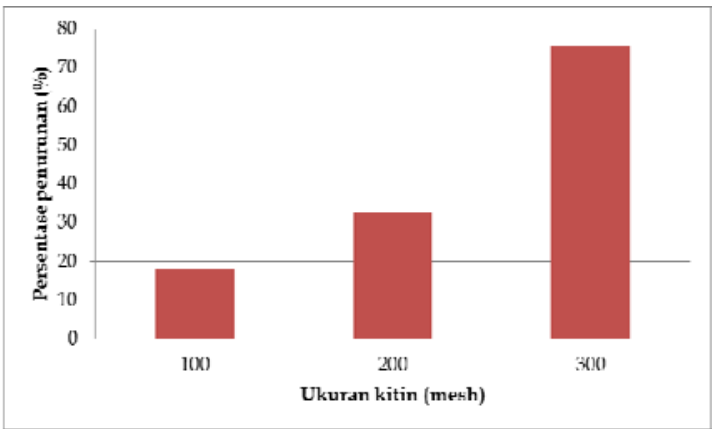

Fig. 3. Graph of the effect of chitin size variations on the percentage of cholesterol reduction in quail eggs

Based on Figure 3 it can be seen that the highest percentage of cholesterol reduction is $75.6 \%$ with 300 mesh chitin size and it can be seen that the smaller the chitin size, the smaller the concentration or cholesterol level in quail eggs which indicates that the greater the percentage decrease. These data indicate that the size of chitin shows the effect on cholesterol adsorption on quail eggs. The adsorption process only occurs in micropores (small pores) [12]. Chitin managed to enter through the pores of the egg and bind 
cholesterol in the egg as evidenced by the cholesterol level of the sample being smaller than the control cholesterol level.

Based on research data, it can be seen that the smaller the size of chitin, the more chitin will enter the egg. The more chitin that enters the egg, the more cholesterol is bound and will produce a greater percentage of cholesterol reduction. In research that has been done about the hypocholesterolemic effects of different chitosan samples, it was found that the smaller the particle size, the greater the binding capacity of cholesterol by chitosan [13].

\section{Variation of Incubation Time on Cholesterol in Quail Eggs}

The effect of incubation time variations of chitin addition to cholesterol levels in quail eggs was examined using five variations of incubation time of $15,30,45,60$, and 120 minutes. Chitin used is chitin with a size of 300 mesh and the concentration used is 0.5 gram / $100 \mathrm{~mL}$ because this concentration produces the largest percentage of cholesterol reduction. Absorbance measured samples and known concentrations can be calculated as a percentage reduction in cholesterol. The results of the effect of incubation time variation on quail cholesterol levels are shown in Figure 4.

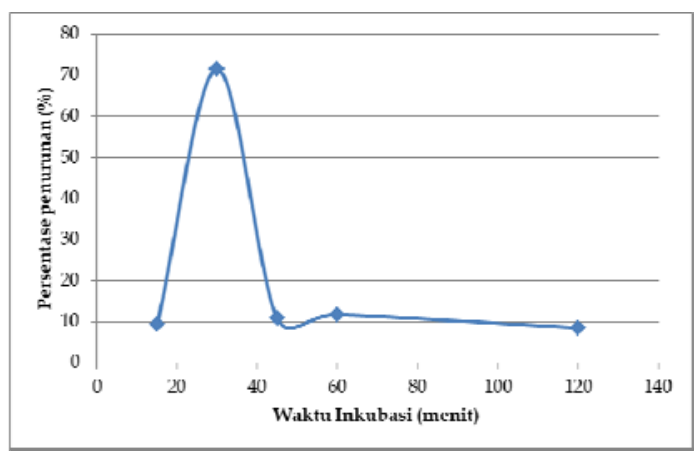

Fig. 4. Graph of the effect of incubation time variations in the addition of chitin to the percentage of cholesterol reduction in quail eggs

Based on Figure 4 it can be seen that the soaking time for 30 minutes produces the greatest percentage of cholesterol reduction, which is $71.5 \%$, which shows that 30 minutes is the optimum time of cholesterol absorption by chitin. After passing the optimum time, which is 45,60 , and 120 minutes, the percentage decrease in cholesterol produced no longer experiences a significant increase. This shows that the longer the incubation time, the binding of cholesterol by chitin will increase and decrease at a certain time.

According to research that has been done about the kinetics of dye adsorption using chitin, when chitin is put into an acid solution, the amino group in the structure of chitin will be positively charged [14]. Then the amino group of positively charged chitin will bind to the hydroxyl group of cholesterol which is negatively charged and the longer it will make the boundary layer (boundary layer) of the adsorbent weaker. The presence of chemical bonds causes the surface of the adsorbent to form a layer where the layer will inhibit the subsequent adsorption process by the adsorbent, so the effectiveness is reduced [15]. In another study, it was also mentioned that after the optimum time the absorption of cholesterol by chitin showed a tendency towards equilibrium, so that the percentage of absorption experienced an increase although only slightly [16].

\section{Cholesterol Binding Mechanism by Chitin}

In this study, chitin can act as an adsorbent that absorbs cholesterol in quail eggs. The more cholesterol that is bound to chitin, the greater the percentage of cholesterol reduction in quail eggs. The adsorption process that occurs is the chemical absorption process which includes the force between valence or electron exchange between the adsorbent and adsorbate [17].

When the egg is soaked with chitin solution, chitin will enter through the pores of the egg and will bind cholesterol in the egg. Chitin is able to bind cholesterol because there is an electrostatic interaction mechanism between chitin and cholesterol. Cholesterol and chitin when mixed will form a binding reaction (electrostatic interaction), so cholesterol is no longer free. This can occur because the acetamide groups on chitin which are positively charged will bind to cholesterol molecules that have a negative charge [18]. Based on this, it can be suspected a reaction between cholesterol and chitin in accordance with Figure 5.

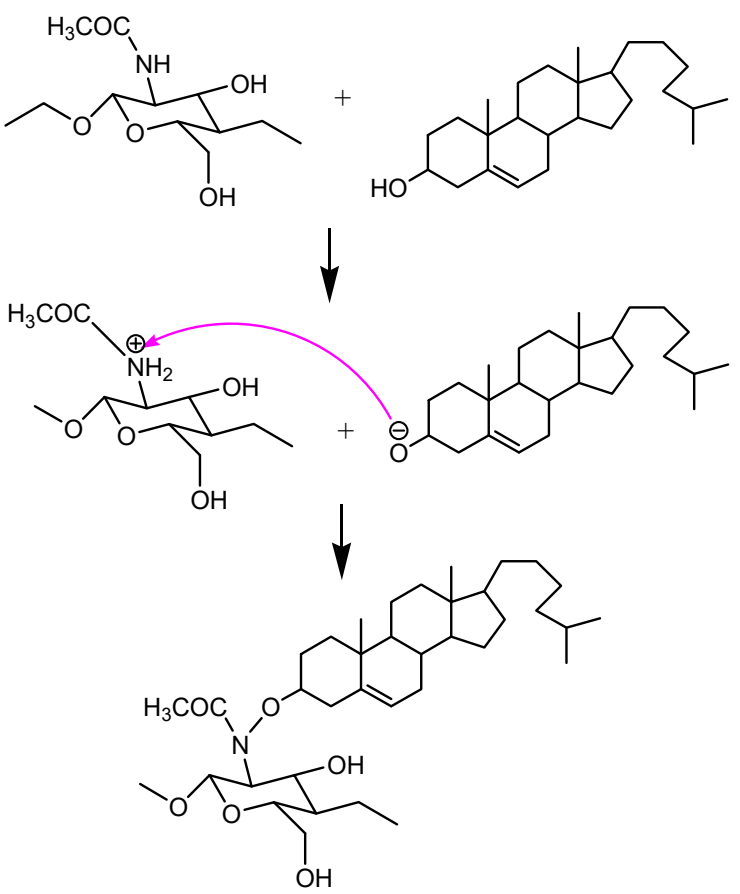

Fig. 5. Supposition mechanism of reaction of cholesterol binding by chitin

Cholesterol molecules that have been linked to chitin form long-chain macromolecules. Chitin fiber which has bound fat into a large mass which the body cannot absorb and increase its excretion with feces [7]. Chitin is included in the fiber group of animals with a total crude fiber content of $72.52 \%$, so that it is grouped into foods with high fiber content. The ability of fiber to reduce blood cholesterol levels is related to the nature of its binding capacity for organic matter including bile acids. The function of bile acids is to emulsify fat into fatty acids that can be absorbed by the body, by binding the bile acids by fiber, the amount of free bile acids will decrease and stimulate the formation of 
new bile acids from cholesterol in the blood so that the concentration of cholesterol in the blood will decrease [5].

\section{CONCLUSION}

Based on the data that has been produced, it can be concluded that the smaller the size of chitin, the easier it is for chitin to bind cholesterol so that it reduces free cholesterol levels and the longer the soaking time the cholesterol binder side will be more saturated with cholesterol so that chitin cannot bind to other cholesterol groups.

\section{REFERENCES}

[1] Nilawati, S. 2008. Care Yourself Kolesterol. Niaga Swadaya : Jakarta.

[2] Bambang. 2003. Effects of Various Cholesterolemix Eggs (Efek Kolesterolemix Berbagai Telur). Jurnal Media Gizi dan Keluarga Vol. 27 Hal $58-65$.

[3] Martati, E. and L. A. Lestari. 2008. The Effect of Chitosan on Lipid Profile of Blood Serum of Sprague Dawley Rats (Pengaruh Pemberian Khitosan Terhadap Profil Lipid Serum Darah Tikus Sprague Dawley). Jurnal Teknologi Pertanian. Vol. 9(3): 157-164.

[4] Park, J., E. Hong, J. Ahn, dan H. Kwak. 2010. Properties of Nanopowdered Chitosan and Its Cholesterol Lowering Effect in Rats. Food Sci. Biotechnol. Vol. 19(6): 1457-1462.

[5] Suryaningsih, L. and A. Parakassi. 2006. Effect of Shrimp Shell Flour (Carapace) as a Source of Chitin in the Ration Against LDL (Low Density Lipoprotein), HDL (High Density Lipoprotein), and Percentage of Carcass (Pengaruh Pemberian Tepung Cangkang Udang (Karapas) sebagai Sumber Khitin dalam Ransum Terhadap Kadar LDL (Low Density Lipoprotein), HDL (High Density Lipoprotein), dan Persentase Karkas). Jurnal Ilmu Ternak. Vol. 6(1): 63-67.

[6] Herdyastuti, Nuniek, Tri Joko Raharjo, Mudasir, and Sabirin Matsjeh 2009. Chitinase and Chitinolytic Microorganism : Isolation, Characterization, and Potential (Kitinase dan Mikroorganisme Kitinolitik : Isolasi, Karakterisasi dan Manfaatnya). Indo. J. Chem. 2009, 9 (1), 37 - 47.

[7] Kusuma, Subhan Hadi. 2016. Ability of Chitin from Mangrove Crab Shells (Scylla spp) in Reducing Cholesterol Viscera of Cattle
Offal.(Kemampuan Kitin dari Cangkang Kepiting Bakau (Scylla spp) dalam Menurunkan Kadar Kolesterol Jeroan Sapi). Jurnal Ilmiah Mahasiswa Keguruan dan Ilmu Pendidikan Unsyiah. Vol 1, No 1.

[8] Cho, Yung Bok, and Seo, Gon. 2010. High activity of acid-treated quail eggshell catalysts in the transesterification of palm oil with methanol. Bioresource Technology 101 (2010) 8515-8519.

[9] Ambarwati, D. A., E. Suprijatna, and S. Kismiati. 2017. Chemical Characteristics of Quail Eggs Due to Feeding Containing Fermented Shrimp Waste Flour (Karakteristik Kimiawi Telur Puyuh Akibat Pemberian Pakan Mengandung Tepung Limbah Udang Fermentasi). Jurnal Peternakan Indonesia, Februari 2017. Vol. 19 (1): 37-45 ISSN 1907-1760 E-ISSN 2460-3716.

[10] Lehninger, A. L. 1982. Principles of biochemistry (Dasar-dasar Biokimia). Alih bahasa, Maggi Thenawijaya. Jakarta : Erlangga.

[11] Taulbee, D. N., dan Maroto-Valer, M. Mercedes. 2000. Centrifugation. University of Kentucky-Center for Applied Energy Research, Lexington, KY, USA : Academy Press.

[12] Manocha, Satish M. 2003. Porous Carbon. Sadhana Journal, Vol. 28 no. 1-2, hal. 335-348.

[13] Liu, Jingna, Zhang, Jiali, dan Xia, Wenshui. 2008. Hypocholesterolaemic effects of different chitosan samples in vitro and in vivo. Food Chemistry 107 (2008) 419-425.

[14] Akkaya, Gulbahar, Ilhan Uzun, and Fuat Guzel. 2007. Kinetics of the adsorption of reactive dyes by chitin. Dyes and Pigments 73 (2007) $168 e 177$.

[15] Murti, S. 2008. Making Activated Carbon from Corn Cob for Ammonia Molecule Adsorption and Chrome Ion (Pembuatan Karbon Aktif dari Tongkol Jagung untuk Adsorpsi Molekul Amonia dan Ion Krom). Skripsi. Depok : Universitas Indonesia.

[16] Hargono, Abdullah, and Sumantri Indro. 2008. Making Activated Carbon from Corn Cob for Ammonia Molecule Adsorption and Chrome Ion (Pembuatan Kitosan Dari Limbah Cangkang Udang Serta Aplikasinya Dalam Mereduksi Kolesterol Lemak Kambing). Reaktor, Vol. 12 No. 1, Juni 2008, Hal. 53-57.

[17] Fransina, Eirene G., and Tanasale, Matheis F.J.D.P. 2008. Studi Kinetika Adsorpsi Biru Metilena pada Kitin dan Kitosan. J. Sains MIPA, Desember 2007, Vol. 13, No. 3, Hal.: 171 - 176.

[18] Hayes, M. 2012. Marine Bioactive Compounds: Sources, Characterization and Applications. United States: Springer US. 